\title{
Reconstructing marine anoxic events and associated microbial responses using organic geochemical proxies in the Upper Devonian New Albany Shale of the Illinois Basin
}

\author{
JIAN CHEN ${ }^{1}$, YUEHAN LU ${ }^{1}$, TAKEHITO IKEJIRI ${ }^{1}$,
} YONGGE SUN $^{2}$, NICHOLAS HOGANCAMP ${ }^{3,4}$

${ }^{1}$ Molecular Eco-Geochemistry Laboratory, Department of Geological Sciences, University of Alabama, Tuscaloosa, AL 35485, USA

${ }^{2}$ Environmental and Biogeochemical Institute, Zhejiang University, Hangzhou Zhejiang 310027, China

${ }^{3}$ Department of Earth and Atmospheric Sciences, University of Houston, Houston, TX, 77204

${ }^{4}$ Hess Corporation, 1501 McKinney Street, Houston, TX, 77010

The New Albany Shale was deposited in epicontinental seas of the Ilinois Basin during the Late Devonian. Marine environmental changes that were coeval with multiple mass extinction pulses may be recorded by the New Albany Shale. Here, we analyzed organic matter from a 95 meter subsurface core of the New Albany Shale from western Kentucky, USA. Our objective was to reconstruct the extent and duration of marine anoxic episodes and determine associated responses and recovery of microbial communities. The core contains the successive Hannibal Saverton Shale, Grassy Greek Shale, Selmier Shale, and Blocher Shale members of the formation. Organic matter in the core is relatively thermally immature, as indicated by $T_{\max }$ of $435-450^{\circ} \mathrm{C}$. Total organic carbon (TOC) ranges between $0.1 \%$ and $18.5 \%$, and $\delta^{13} \mathrm{C}$ of TOC ranges between $-31.0 \%$ and $-27.0 \%$. Interestingly, we observed four positive $\delta^{13} \mathrm{C}_{\text {TOC }}$ excursions that may indicate anoxic deposits corresponding to four extinction pulses, Givetian-Frasnian, Lower Kellwasser, Upper Kellwasser, and Hangenberg. Conodont biostratigraphy data are being collected to confirm the identification of these extinction pulses. Molecular biomarkers being analyzed include normal and branched alkanes, hopanes, steranes, and polycyclic aromatic hydrocarbons. Preliminary biomarker data show particularly low pristane/phytane ratios during the positive excursions of $\delta^{13} \mathrm{C}_{\mathrm{TOC}}$, confirming the correlation between anoxia and $\delta^{13} \mathrm{C}_{\text {TOC. }}$. Further analyses will target biomarkers indicating anoxia (e.g., aryl isoprenoid) and microbial community compositions (e.g., hopane/sterane, methylhopane) to understand microbial response and recovery during the four anoxic episodes. 